Jurnal Keperawatan Silampari

Volume 3, Nomor 1, Desember 2019

e-ISSN: 2581-1975

p-ISSN: 2597-7482

DOI: https://doi.org/10.31539/jks.v3i1.843

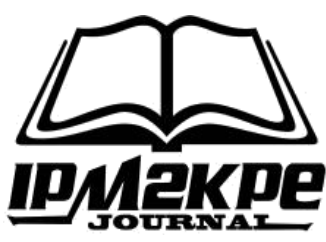

\title{
DETEKSI DINI GANGGUAN MENTAL DAN EMOSIONAL PADA ANAK YANG MENGALAMI KECANDUAN GADGET
}

\author{
Dwi Wulandari ${ }^{1}$, Dilfera Hermiati ${ }^{2}$ \\ Program Studi Ilmu Keperawatan, Universitas Dehasen Bengkulu ${ }^{1,2}$ \\ dwiwulandari@unived.ac.id ${ }^{1}$
}

\begin{abstract}
ABSTRAK
Penelitian ini bertujuan untuk melakukan skrining dini dan angka kejadian gangguan mental dan emosional yang ditujukan untuk anak yang mengalami kecanduan gadget usia 3-6 tahun. Metode penelitian menggunakan deskriptif analitik dengan melihat gambaran kejadian gangguan mental dan emosional pada anak usia 3-6 tahun. Hasil Penelitian menunjukan dari 100 responden sebanyak 66 (66\%) responden dengan tingkat kecanduan tinggi, 34 (34\%) responden dengan tingkat kecanduan rendah. sebanyak 41 (41\%) responden dengan Mental dan emosional Normal, 59 (59\%) responden dengan suspek gangguan mental dan emosional. Simpulan, sebagian besar anak mengalami kecanduan gadget dan sebagian besar anak beresiko mengalami gangguan emosial jika orang tua tidak melakukan tindakan bijak dalam penggunaan gadget.
\end{abstract}

Kata Kunci: Gangguan Mental Emosional, Kecanduan Gadget

\section{ABSTRACT}

This study aims to conduct early screening and the incidence of mental and emotional disorders aimed at children who are addicted to gadgets aged 3-6 years. The research method uses descriptive analytic by looking at the description of the incidence of mental and emotional disorders in children aged 3-6 years. The results showed of 100 respondents as many as 66 (66\%) respondents with a high level of addiction, 34 (34\%) respondents with a low level of addiction. as many as 41 (41\%) respondents with Mental and emotional Normal, 59 (59\%) respondents with suspected mental and emotional disorders. Conclusion, most children are addicted to gadgets and most children are at risk of experiencing social problems if parents do not act wisely in the use of gadgets.

Keywords: Emotional Mental Disorders, Gadgets Addiction

\section{PENDAHULUAN}

Gadget saat ini marak diperbincangkan dikonsumsi oleh masyarakat saat ini karna kecanggihan teknologi gadget diciptakan dalam bentuk perangkat kecil yang fleksibel dan nyaman dibawa kemana saja. Bukan hanya orang dewasa, saat ini anak-anak mampu menggunakan gadget dalam kehidupan sehari-hari, dan mereka nyaman dalam menggunakan sehingga dapat mengakibatkan terjadinya kecanduan gadget yang dapat berdampak pada perkembangan anak berupa gangguan mental, emosi dan perilaku negatif anak. Gangguan mental, emosi dan perilaku merupakan masalah yang serius 
dalam perkembangan intelektual anak serta dapat menurunkan produktivitas, kualitas hidup, dan tumbuh kembang anak (Maulida, 2013).

Sebuah survei penelitian yang dilakukan melalui polling melalui saluran televisi Channel News didapatkan bahwa hasil survei menunjukkan sebanyak 47 persen dari orang tua mengungkapkan bahwa anak mereka banyak menghabiskan waktu seharian di depan layar gadget ada yang membuka youtube, game, bahkan ada yang menggunakan sebagai sarana belajar seperti coloring, dll. Sedangkan sebanyak 43 persen lainnya mengaku bahwa anak mereka telah memiliki ikatan emosi dengan perangkat mobile yang dimiliki seperti menangis, marah jika gadget mereka diambil. Rata-rata anak, dari survei itu, menghabiskan waktu rata-rata lebih dari tiga jam untuk berkutat di depan layar gadget dalam sehari. Biasanya mereka bermain games, melihat video atau Youtube, dan berinteraksi di sosial media, hasil penelitian yang dilakukan Profesor Sonia Livingstone dari London School of Economic (Ramadhan, Agung, 2017; Depkes RI, 2013).

Beberapa kasus yang tengah marak akhir-akhir ini terkait gangguan kejiwaan (mental, emosional dan perilaku) yang dialami anak akibat kecanduan gadget pada anak merupakan masalah ini dianggap penting dan harus di waspadai oleh seluruh orangtua yang memiliki anak terutama usia presekolah dengan kebiasaan memainkan gadget. Untuk menghindari hal tersebut perlu dilakukan deteksi dini dalam penilaian status mental dan emosional anak sejak dini pada usia 3-6 tahun (IDAI, 2013)

Kurang pengawasan dan pemahaman orang tua terhadap gejala-gejala maupun dampak dari gangguan gadget akan membuat penanganan dan prognosis yang lebih buruk pada anak, akibat kurangnya pengetahuan dari orang tua Mengenai akibat lanjut yang dapat terjadi jika aktifitas penggunaan gadget ini terus dilakukan. Akibat lanjut yang dapat terjadi jika tidak dilakukan tindakan segera dapat mempengaruhi perkembangan mental dan emosional pada anak-anak tersebut yang akan berpengaruh pada kehidupan sosial anak dimasyarakat, mengalami kesulitan dalam menerima belajar, dan lain-lain. Oleh karena itu, diperlukan skrining dini dan diagnosis dini untuk mengetahui gangguan tersebut (IDAI, 2013; Erol dkk, 2005). Gangguan ini dapat diukur dan dideteksi dengan menggunakan Kuisioner Masalah Mental dan Emosional (KMME) yang bertujuan untuk skrining dini dalam melakukan deteksi adanya gangguan mental dan emosional pada anak yang ditujukan untuk anak pada rentang usia 3-6 tahun. Kuesioner Masalah Mental dan Emosional (KMME) belum dapat mendiagnosis Secara pasti anak tersebut mengalami gangguan mental dan emosional atau tidak, namun dapat mensuspek anak tersebut mengalami simptom gangguan mental dan emosional. Dengan dilakukan skrining orang tua dapat melihat kelakuan negatif yang dilakukan anak terkait emosional anak, sehingga orang tua dapat segera menindaklanjuti hasilnya, misalnya, jika anak tersebut suspek mengalami gangguan mental dan emosional, orang tua dapat segera konsultasi ke dokter anak, psikolog anak dan ahli kejiwaan untuk penegakkan diagnosis (Erol dkk, 2005).

Saat ini belum terlalu banyak penelitian yang mengacu pada gangguan mental dan emosional secara lebih luas terutama pada anak di Indonesia yang merupakan dampak dari kecanduan gedget yang merupakan hasil negatif dari perkembagan teknologi yang sedang berkembang saat ini. Meskipun ada beberapa faktor risiko lain yang menjadi penyebab terjadinya gangguan emosional pada anak misalnya jenis kelamin anak, jumlah saudara dalam keluarga, trauma emosional pada anak, kegagalan dalam bersosialisasi di masyarakat akibat isolasi yang dilakukan dan pola asuh yang tidak baik serta riwayat komplikasi saat kelahiran anak dan masa awal bayinya, riwayat penyakit 
kronis, ketidakharmonisan dalam keluarga, faktor keturunan akibat orang tua menderita sakit mental atau ketergantungan obat, dan pola asuh orang tua. dan lain-lain, beberapa faktor diatas merupakan salah satu faktor pencetus gangguan mental dan emosional akan bermunculan lebih dini (Bayer, 2011). Fenomena yang terjadi ini dapat menjadi fenomena gunung es serta menjadi beban dan masalah baru kesehatan bagi pemerintah, dan menjadi penyebab rusaknya generasi penerus bangsa (CDC, 2013).

Oleh karena itu, dibutuhkan penelitian yang dapat menyediakan data prevalensi gangguan mental dan emosional pada anak, yang diakibatkan gadget. Kelurahan sawah lebar adalah salah satu tempat yang tepat untuk dilakukan penelitian. Alasannya adalah kelurahan ini terletak di kota Bengkulu, masyarakatnya heterogen (mengurangi bias) dan pola modernisasi yang sangat mungkin akan berpengaruh pula pada perkembangan mental dan emosional anak. Diharapkan hasil penelitian tersebut dapat menjadi data yang berguna untuk penelitian selanjutnya dan mampu mendasari kebijakan maupun prevensi yang akan dilakukan, sekaligus skrining dini bagi anak-anak yang menjadi objek penelitian.

\section{METODE PENELITIAN}

Jenis penelitian mengunakan metode deskriptif analitik yaitu dengan melihat gambaran kejadian gangguan mental dan emosional pada anak usia 3-6 tahun. Populasi pada penelitian ini adalah seluruh anak usia 3-6 tahun di wilayah kerja puskesmas Sawah Lebar tahun 2018 sebanyak 467 orang. Sampel penelitian ini adalah Anak usia 36 tahun sebanyak 100 orang dengan menggunakan teknik purposive random sampling yaitu teknik penentuan sampel dengan memenuhi karakteristik tertentu. Karakteristik yang harus dipenuhi anak usia 3-6 tahun yang menggunakan gadget minimal 1 jam setiap harinya dalam kurun waktu minimal 3 bulan. Adapun yang mengisi kuisioner adalah significant others yang mana dapat diisi oleh orang tua anak (dalam hal ini adalah ibu).

\section{HASIL PENELITIAN \\ ANALISIS UNIVARIAT \\ Hasil Penilaian Kecanduan Gadget Anak}

Tabel.1

Hasil Penilaian Kecanduan Gadget pada Anak Pra Sekolah

\begin{tabular}{|c|c|c|c|}
\hline No & Kategori Kecanduan Gadget & Frekuensi $(\mathrm{F})$ & Persentase $(\%)$ \\
\hline 1 & Tingkat Kecanduan Tinggi & 66 & 66 \\
\hline 2 & Tingkat Kecanduan Rendah & 34 & 34 \\
\hline Tota & & 100 & 100 \\
\hline
\end{tabular}

Berdasarkan tabel 1 diketahui dari 100 responden sebanyak 66 (66\%) responden dengan tingkat kecanduan tinggi, 34 (34\%) responden dengan tingkat kecanduan rendah. 


\section{Gangguan Mental dan Emosional Anak}

Tabel. 2

Hasil Penilaian Ganggun Mental dan Emosional pada Anak Pra Sekolah

\begin{tabular}{clcc}
\hline No & Gangguan Mental dan Emosional & Frekuensi (F) & Persentase (\%) \\
\hline 1 & Normal & 41 & 41 \\
2 & suspek gangguan mental dan emosional & 59 & 59 \\
Total & & 100 & 100 \\
\hline
\end{tabular}

Berdasarkan tabel 2 diketahui dari 100 responden sebanyak 41 (41\%) responden dengan mental dan emosional normal, 59 (59\%) responden dengan suspek gangguan mental dan emosional.

\section{Umur}

Tabel. 3

Distribusi Frekuensi Umur pada Anak Pra Sekolah

\begin{tabular}{crcc}
\hline No & \multicolumn{1}{c}{ Umur } & Frekuensi (F) & Persentase (\%) \\
\hline 1 & 3-3 Tahun 11 Bulan & 16 & 16 \\
2 & 4-5 Tahun 11 Bulan & 41 & 41 \\
3 & 5-6 Tahun & 43 & 43 \\
Total & 100 & 100 \\
\hline
\end{tabular}

Berdasarkan tabel 3 diketahui dari 100 responden sebanyak $16(16 \%)$ responden dengan Umur3-3 tahun 11 bulan, 41 (41\%) responden dengan Umur 4-5 tahun 11 bulan, dan $43(43 \%)$ responden dengan umur 5-6 tahun.

\section{Jenis Kelamin}

Tabel. 4

Distribusi Frekuensi Jenis Kelamin pada Anak Pra Sekolah

\begin{tabular}{cccc}
\hline No & Jenis Kelamin & Frekuensi (F) & Persentase (\%) \\
1 & Perempuan & 42 & 42 \\
2 & Laki-laki & 48 & 48 \\
Total & 100 & 100 \\
\hline
\end{tabular}

Berdasarkan tabel 4 diketahui dari 100 responden sebanyak 48 (48\%) responden dengan Jenis kelamin Laki-laki, 42 (42\%) responden dengan Jenis Kelamin Perempuan.

\section{PEMBAHASAN}

\section{Gambaran Penilaian Kecanduan Gadget pada Anak Pra Sekolah}

Hasil penelitian ini menunjukkan bahwa sebagian besar responden dengan tingkat kecanduan tinggi. Saat dilakukan wawancara kepada orang tua mengungkapkan bahwa diawali dengan meminjamkan sampai membelikan gadget yang canggih dengan model yang sesuai dengan keinginan anak, demi memberika kebahagiaan pada anak, mengikuti trend. Selain itu beberapa orang tua dengan sengaja membiarkan anak untuk tidak keluar rumah dan melakukan banyak aktifitas didalam dan diluar dirumah dengan 
memberikan gadget pada anak, agar memiliki kesibukan baru yang mengajarkan anak untuk diam disuatu tempat dengan menggunakan gadget. Selain itu orangtua yang memiliki karir diluar rumah gadget sengaja difasilitasi untuk digunakan agar akatifitas anak terpantau dan dapat berkomunikasi dengan anak yang ada dirumah, sehingga orang tua mengetahui semua aktifitas yang dilakukan anak.

Sedangkan ibu dengan pekerjaan sebagai ibu rumah tangga membelikan gadget pada anak dengan tujuan mengalihkan perhatian sianak agar tidak menganggu aktifitas ibu dalam mengerjakan pekerjaan rumah tangga. Awalnya tujuan mereka berhasil, untuk komunikasi dan sebagai pengalihan perhatian pada anak. Namun lama-kelamaan anak mulai mencoba lebih aktif untuk mencoba fitur serta aplikasi lain yang lebih menarik, dan menantang sesuai dengan keinginan mereka masing-masing. Hal ini akan membuat anak akan lebih terfokus pada gadgetnya dan mulai meninggalkan dunia bermain mereka, dan merasa lebih nyaman dengan beberapa fitur yang ditawarkan di gadget. Anak akan lebih individual dan kurang peka terhadapa lingkungan sekitarnya. Penggunaan gadget yang berlebihan akan berdampak buruk pada suasana emosial anak anak.

Beberapa anak yang menghabiskan waktu dengan bermain gadget akan lebih emosional, pemberontak jika diganggu saat asyik bermain game, selain itu anak mengeluarkan emosional yang arogan, bahkan memukul, menangis kencang, sampai pada tahap keputusasaan jika gadget tidak dikembalikan dengan segera. Hal ini akan membuat anak mengalami gangguan mental dan emosional, sehingga akan berdampak negatif jika tidak dilakukan terapi dengan segera, selain itu anak juga menunjukan sikap malas dalam mengerjakan rutinitas sehari-hari, respon yang kurang jika dipanggil, sampai dengan lupa waktu dan kegiatan lainnya. Bahkan anakpun lupa untuk makan, karena sedang asyik menggunakan gadgetnya. Yang lebih mengkhawatirkan lagi, jika mereka sudah tidak tengok kanan kiri atau mempedulikan orang disekitarnya,bahkan menyapa kepada orang yang lebih tuapun mereka menolak, sehingga akan menganggu interaksi sosial anak dirumah, bahkan diluar rumah (Jonatan, 2015).

Orangtua harus mengetahui bahwa periode perkembangan atau masa keemasan pada anak saat berusia 1-5 tahun, masa dimana anak banyak belajar dan mengetahui hal baru, yang penting untuk pertumbuhan anak. Pada Rentang usia anak 1-5 tahun disebut the golden age, pada periode ini seluruh aspek perkembangan pada kecerdasan anak, seperti kecerdasan intelektual anak, perkembangan emosi anak, dan daya tangkap perkembangan spiritual mengalami perkembangan yang sangat pesat dan luar biasa, sehingga perkembangan pada tahap ini akan menjadi tolak ukur dalam menentukan perkembangan selanjutnya. Ketika anak berada pada periode the golden age maka semua informasi yang yang didapatkan anak baik di lingkungan rumah atau di luar rumah mampu diserap dengan cepat pada periode ini. Sehingga pada periode ini semua informasi yang didapat akan ditiru dengan anak secara cepat karena pada masa ini terjadi proses imitasi perilaku pada anak, anak biasanya lebih smart dari yang kita pikir, lebih cerdas dari yang terlihat dan akan menjadi dasar terbentuknya karakter pada anak, serta pembentukan kepribadian, dan peningkatan kemampuan kognitifnya. Sehingga orang tua harus lebih siap dan selektif dalam mendidik anak pada usia tersebut, dan jangan pernah kita anggap remeh anak pada usia tersebut.

Pada dasarnya penggunaan teknologi gadget pada saat ini memiliki dampak positif dan negatif bagi anak, diantaranya dalam pembentukan pola pikir anak yaitu mampu membantu anak dalam mengatur kecepatan bermainnya, mengolah strategi dan analisa dalam permainan, dan membantu anak dalam meningkatkan kemampuan otak 
kanan selama dalam pengawasan yang baik oleh orang tua. Akan tetapi dari beberapa damapak positif tadi, jika di tinjau dan diteliti lebih lanjut maka faktor dominan lebih ke arah dampak negatif yang berpengaruh terhadap perkembangan anak. Beberapa efek negatif yang dapat terjadi seperti radiasi dalam gadget dapat berdampak merusak jaringan syaraf dan perkembangan otak pada anak bila anak sering menggunakan gadget, dapat menurunkan daya aktif anak dalam beraktifitas karna hanya dalam posisi monoton, tanpa ada aktifitas fisik seperti anak pada umumnya, selain itu mengurangi kemampuan anak untuk berinteraksi dengan orang lain, sehingga anak menjadi lebih individual dengan zona nyamannya bersama gadget sehingga kurang memiliki sikap peduli terhadap teman bahkan orang lain, bahkan anak memiliki dunianya sendiri (Maulida, 2013).

Ada beberapa perilaku anak yang mengalami kecanduan gadget yang harus diwaspadai oleh guru maupun orang tua yaitu: (1) Ketika keasyikan dengan gadget anak jadi kehilangan minat dalam kegiatan lain. (2) Anak mulai tidak tertarik melakukan interaksi, atau bergaul dengan teman sebaya untuk bermain diluar rumah, (3). Anak mulai menunjukan emosional yang kadang tidak bisa dikontrol, bahkan tantrum ketika orang tua mengambil, merenut, atau melarang anak saat sedang asyik menggunakan gadget. (4) anak mulai menunjukan perilaku negatif, dengan berani berbohong atau mencuri-curi waktu untuk bermain gadget saat orang tua sedang asyik beraktifitas, atau saat sedang tidur. Beberapa perilaku diatas merupakan sebagian tanda dan gejala pada anak bahwa mereka sedang membutuhkan bantuan dalam menghentikan aktifitasnya dengan kecanduan bermain gadget. Meskipun sebenarnya bermain gadget memiliki beberapa manfaat untuk membentuk sikap cekatan, melatih fokus, serta meningkatkan kecakapan dalam berbahasa inggris (Erol Dkk, 2005).

Dampak negatif pada anak yang menggunakan gadget dapat membuat anak mengalami ketagihan, sampai dengan fase kecanduan gadget. Anak akan membuang waktu sia-sia dalam bermain, bahkan anak menahan rasa lapar, haus, dan keinginan untuk melakukan toileting. Anak-anak mulai malas melakukan aktiftas rutin seperti belajar, bermain, makan, melakukan aktifitas seperti bermain bola pada anak laki-laki, pada anak perempuan bermain bersama teman sebaya, padahal beberapa aktiftas berpengaruh penting dalam mendukung kematangan dan perkembangan anak di berbagai aspek perkembangan yang ada pada dirinya, dan penunjang dalam perkembangan otak. Jika anak dalam waktu lama terpapar dalam penggunaan gadget, dan menjadikan gadget sebagai aktiftas rutin yang dilakukan sehari-hari maka hal ini menjadi salah satu faktor penyebab terganggunya perkembangan otak. Sehingga dampak lanjut yang dapat terjadi adalah hambatan dalam kemampuan berbicara, (tidak lancar komunikasi) karena anak jarang melakukan proses komunikasi akibat asyik berinteraksi dengan gadget, dapat mengakibatkan terjadinya gangguan dalam mengeskpresikan pikirannya, karna hanya memikirkan gadget adalah teman terbaiknya saat ini dalam mengekspresikan dirinya, sehingga minimnya pengalaman anak dalam berinteraksi dengan lingkungan.

Banyaknya fitur atau aplikasi yang ditawarkan dalam gadget yang tidak sesuai dengan usia anak, tidak mengedukasi dan merusak moral agama pada anak, serta menganggu kesehatan anak. Penggunaan gadget dalam waktu lama dapat menganggu kesehatan mata anak, anak juga tidak memiliki kemauan dan ketertarikan dalam hal membaca buku, karena terbiasa pada objek bergambar dan bergerak. Aktifitas bermain menjadi aktiftitas yang tidak menyenangkan, karna asyik berinteraksi dengan gadget, 
sehingga kondisi ini membuat mereka lebih bersifat individualis atau menyendiri (Hastuti, 2012).

Anak-anak lebih tertatik menggunakan gadget sehariaan saat hari libur dan akhir pekan ketimbang bermain dengan teman bermain untuk sekedar bermain bola, bersepeda dilapangan. Anak akan mengalami penurunan daya konsentrasi, serta semakin terbukanya akses internet dalam gadget yang menampilkan segala hal yang semestinya belum waktunya dilihat oleh anak-anak, sehingga anak akan meniru tentang apa yang ia lihat, karna akan terjadi fase imitasi pada anak sesuai dengan tahap perkembangan. Peran orang tua harus secara bijak pada anak dalam mengawasi dan mendampingi anak dalam penggunaan gadget saat bermain. Kebiasaan anak-anak dalam penggunaan teknologi tidak bisa dipungkiri, namun ada baiknya orang tua memberi batasan waktu pada anak dalam bermain gadget. Karena alasan kesehatan dan radiasi, kegiatan bermain penting bagi perkembangan kognitif, sosial, emosional dan kepribadian anak, dan mengajari anak untuk bisa belajar dan memahami hubungan antara dirinya dan lingkungan sosialnya (Widiawati, 2014).

Radiasi pada gadget dapat menganggu perkembangan otak anak radiasi dari penggunan gadget yang tergolong gelombang RF. Radiasi RF pada level tinggi serta dapat merusak jaringan tubuh, serta memiliki kemampuan untuk memanaskan jaringan tubuh seperti oven microwave memanaskan makanan. Efek dari radiasi ini dapat merusak jaringan tubuh karena tubuh kita tidak dilengkapi sistem ketahanan untuk mengantisipasi sejumlah panas berlebih akibat radiasi RF. Hasil Penelitian menunjukkan bahwa radiasi nonionisasi (termasuk gelombang RF) menimbulkan efek jangka panjang. Penyakit yang berpotensi timbul karena radiasi gadget adalah kanker, tumor otak, alzheimer, parkinson, sakit kepala. Dibanding orang dewasa, anak-anak zaman sekarang sudah mengenal teknologi nirkabel sejak kecil sehingga waktu 'bersentuhan' dengan radiasi lebih panjang. Hal ini disebabkan karena di usia 12-15 tahun. anak mengalami proses bangkitnya akal. nalar dan kesadaran diri. Dalam masa ini terdapat energi dan kekuatan fisik serta tumbuh keinginan tahu dan keinginan cobacoba. Data memperlihatkan bahwa ketika radiasi dari gadget memasuki kepala. orang dewasa menyerapnya sebanyak 25\% anak usia 12 tahun sebanyak $50 \%$ dan tertinggi pada usia 5 tahun yaitu 75\%. Oleh karenanya, risiko radiasi ini akan lebih besar pada anak yang sudah 'akrab' dengan gadget di usia kurang dari 16 tahun (Suwarsi, dkk, 2015).

Orang tua harus memiliki peran yang lebih aktif, dalam menemani anak dalam proses pertumbuhannya, Jangan sampai orangtua mengandalkan gadget untuk menemani anak agar tidak beraktifitas diluar rumah dan mebih memudahkan orang tua dalam mengontrol anak. Sebagai orang tua hendaknya mengontrol setiap konten, program, game, tayangan yang ada di gadget, yang merupakan salah satu cara yang paling efektif dalam mengontrol setiap aktifitas anak dalam penggunaan gadget. Selama usia 3-5 tahun hendaknya orang tua lebih banyak mengajak anak untuk berdiskusi, tanya jawab dalam waktu luang, dan berdiskusi tentang aktifitas yang anak sukai. Orang tua harus meluangkan waktu bermain bersama atau hanya sekedar bercanda kepada anak disel-sela aktifitas yang padat, sehingga dapat dinilai seberapa perkembangan pada anak dalam mengembangkan daya imajinasi dan kreatifitasnya (Widyawati, 2014).

Kesiapan orang tua diperlukan dalam melakukan pengawasan dan pendampingan saat anak bermain gadget. Oleh karena itu, orangtua harus menyadari perannya dalam pemanfaatan gadget pada anak, sehingga penggunaan gadget digunakan secara tepat. Orang tua perlu menerapkan sejumlah aturan kepada anak-anknya dalam menggunakan 
gadget. Pemanfaatan gadget secara efektif penting dilakukan dengan pendampingan orang tua dalam menjelaskan pada anak mengenai konten yang digunakan, dan keterbatasan dalam akses data. Hal yang harus dilakukan orang tua dalam memperkenalkan teknologi tepat guna pada anak Pertama, orang tua memberikan kesempatan pada anak untuk belajar mengggunakan gadget untuk belajar dan berinteraksi sejak dini, dalam penggunaan teknologi secara tepat. Penggunaan gadget saat ini tidak dapat dihindari pada saat ini dan masa yang akan datang. Gadget mempunyai efek-efek tertentu terhadap penggunanya, termasuk efek fisik pada seseorang. Kemudian sudah jelas manfaat dan tujuan dalam penggunaan gadget yaitu memberikan arahan kepada anak bagaimana menggunakan gadget dengan benar, serta manfaat positif gadget dapat meningkatkan kemampuan intelektual anak, tergantung dari konten yang diperlihatkan.

Posisi duduk juga perlu diajarkan, untuk mengatur letak cahaya dan jarak pandang mata dengan gadget, untuk menghindari kerusakan mata pada anak, karena jarak pandang yang terlalu dekat akan mengganggu penglihatan anak. Kedua, pilihlah aplikasi yang mendidik, berupa gambar, simbol, dan sesuatu game yang memiliki nilai sebagai media pembelajaran, yang sesuai dengan kebutuhan anak-anak, dan harus disesuaikan dengan usia dan kemampuan anak. Semua jenis permainan, sosial media, video youtube itu semua harus melewati pengawasan orangtua. Karena beberapa tayangan yang mengandung unsur kekerasan dan pornografi rentan terjadi atau mudah didapatkan pada konten tersebut. Sebagai orangtua berikan penjelasan secara bijak setiap fungsi dari konten yang ada pada gadget. Anak-anak akan bisa menerima penjelasan sebelum mereka asik menggunakan gadgetnya (Jonatan, 2015).

Karna hasil penjelasan ini diharapkan anak-anak mampu memahami bahwa penggunaan gadget dapat digunakan seperlunya baik dengan sesama anggota keluarga ataupun dengan warga sekitar lingkungan, dan dapat digunakan secara bijak. Hendaknya orangtua harus lebih tau tentang semua konten yang ada pada gadget anakanaknya. Ketiga, tempatkan gadget di ruang umum, sehingga mampu terpantau dengan baik, memberikan kursi atau meja yang nyaman untuk bermain gadget, untuk menghindari terjadinya cidera selama penggunaan, selain itu posisi tidur tidak baik untuk kesehatan mata. Keempat, mengatur durasi penggunaan gadget. Orang tua jangan sampai membiarkan anak-anak asik dengan gadget, karna dapat membuat anak-anak lupa waktu. Orangtua harus memberikan batasan waktu penggunaan gadget pada anakanaknya. Orangtua harus selalu membangun interaksi yang baik dengan anaknya, dan memberikan contoh penggunaan gadget secara positif.

Karena berdasarkan hasil wawancara anak yang mahir menggunakan gadget pada awalnya mencontoh orang tua, Untuk itu. contoh yang baik dalam menggunakan gadget sejak awal penting untuk dilakukan. Kelima, orangtua membantu agar anak-anak dapat membuat keputusan sendiri, biasanya anak ingin menciptakan suasana yang baru tetapi tidak berani berkomunikasi dengan orangtua. Orangtua harus selalu mengajak diskusi bahkan mengajak bercerita supaya anak bisa menampilkan atau berkreasi dengan ideide yang ada di pikirannya. Tanamkan pada diri anak tentang rasa takut terhadap Tuhan sehingga jika tidak ada orangtua dia tahu bahwa Tuhan memperhatikan dan melihat apa yang dilakukan selama menggunakan gadget (Muhibbin, 2003). 


\section{Gambaran Penilaian Gangguan Mental dan Emosional pada Anak Prasekolah}

Hasil penelitian diketahui bahwa sebagian besar responden dengan suspek gangguan mental dan emosional. Menurut hasil penelitian dari Anggrahini (2013) hasil penelitian menunjukan bahwa selama anak menggunakan gadget, ketika berada di rumah anak menjadi susah diajak berkomunikasi, tidak peduli dan kurang berespon pada saat orangtua mengajaknya untuk berkomunikasi atau berbicara. Beberapa masalah tersebut dapat menimbulkan gangguan komunikasi antara anak dengan orang tuanya, lingkungannya, bahkan teman sebayanya. Penelitian yang dilakukan oleh Yulia (2015) menunjukkan bahwa ada pengaruh penggunaan gadget pada perkembangan psikososial anak. Pada saat menggunakan gadget, waktu mereka terbuang untuk terus bermain game. Dalam penelitian Hovart menjelaskan bahwa kecanduan gadget tidak hanya terhadap permainan atau konten yang ada, akan tetapi juga pada aktivitas tertentu yang dilakukan berulang-ulang oleh anak dan menimbulkan dampak negatif begitupun dengan kecanduan terhadap gadget. Hal ini akan menghambat proses sosialisasi anak dan akan menimbulkan ketergantungan pada gadget tersebut. Tingkat pendidikan orang tua berpengaruh pada risiko timbulnya terjadinya gangguan emosi dan perilaku yang terjadi pada anak (Hastuti, 2012).

Penelitian oleh Harahap dkk menyebutkan bahwa tingkat pendidikan yang rendah memiliki dapat menyebabkan kurangnya pengetahuan tentang cara merawat anak dengan baik, sehingga berisiko menimbulkan gangguan emosi dan perilaku. Hasil penelitian jurnal Preventive Medicine Reports memaparkan bahwa dalam waktu satu jam anak menatap layar gadget, anak-anak mengalami perubahan perilaku cenderung menjadi lebih tidak peduli, kontrol diri berkurang, dan stabilitas emosi juga menurun, bahkan meningkat. Peningkatan risiko kecemasan dan depresi pada anak yang sering menggunakan gadget pada anak. Hasil penelitian juga menemukan pada usia 14-17 tahun lebih berisiko terhadap efek buruk semacam itu, tetapi memiliki korelasi pada anak-anak dan balita yang lebih kecil, yang otaknya masih dalam proses berkembang. Selain itu pada umumnya anak-anak yang diberikan gadget sejak dini akan bermain gadget lebih dari dua jam sehari sehingga mengakibatkan gangguan speech delay, anti sosial, dan otak cenderung lebih lemot karena kurangnya stimulasi dan interaksi dengan lingkungan sosialnya.

Gangguan Attention Deficit Disorder (ADD) juga bisa timbul karena seringnya melihat tampilan warna menarik di layar gadget. Akibatnya anak akan cepat bosan dan sering mengamuk ataupun lebih temperamental/tantrum. "Anak lebih perlu berinteraksi dekat dengan orang tua dibandingkan dengan gadget, mendekap dan berkomunikasi dalam banyak hal. Kebiasaan penggunan gadget dari mulai masa anak-anak akan memicu timbulnya perubahan sikap kearah negatif egosentris. Perubahan sikap ini tentunya berdampak tidak baik dalam lingkungan sosial. Penggunaan gadget yang terlalu lama dan sering secara tidak langsung membuat anak terbiasa untuk tidak peduli satu sama lainnya, baik ketidak pedulian pada dirinya, dan lingkungan. Selain itu akan muncul rasa kurang empati kepada lingkungannya, karna hanya berfokus pada satu benda, bahkan anak asyuk dengan dunianya sendiri (Suwarsi, 2015; Widyawati, 2014).

\section{SIMPULAN}

Berdasarkan hasil penelitian mengenai deteksi dini deteksi dini gangguan mental dan emosional pada anak yang mengalami kecanduan gadget dapat ditarik kesimpulan sebagai berikut: Bahwa sebagian besar anak mengalami kecanduan gadget dan sebagian besar anak beresiko mengalami gangguan emosial jika orang tua tidak melakukan 
tindakan bijak dalam penggunaan gadget, usia 1-5 tahun merupakan usia keemasan dalam membentuk semua karakter diri, sehingga pendampingan dan pola asuh yang baik dari orang tua sangan dibutuhkan dalam proses tumbuh dan kembang anak dari segala aspek.

Kini kehidupan sosial anak-anak lebih terpengaruh oleh teknologi yang sedang berkembang saat ini. Lebih sering anak usia dini melakukan interaksi dengan gadget serta dunia maya saat ini mempengaruhi daya pikir anak terhadap sesuatu di luar hal tersebut, ia juga akan merasa asing dengan lingkungan sekitar karena kurangnya interaksi sosial. Selain itu anak kadang tidak dapat membedakan dunia nyata, dan imajinasi yang ia dapatkan melalui gadget sehingga kadang anak takut akan keramaian, dan sesuatu kondisi tertentu.

Namun kemajuan teknologi saat ini sangat penuh dengan kreatifitas jika pemanfaatannya diimbangi dengan interaksi anak-anak dengan lingkungan sekitarnya. Anak-anak diharapkan tahu bagaimana cara memanfaatkan teknologi secara tepat, serta adanya pengawasan ketika anak-anaknya bermain gadget agar mereka tidak terlalu tergantung dengan gadget dan tidak melupakan untuk bersosialisasi dengan lingkungan sekitarnya.

\section{SARAN}

Kepada orang tua, guru, dan lembag kesehatan terkait, mari kita selamatkan generasi penerus bangsa dengan bijak memperkenalkan gadget pada anak. Menjadi orang tua dari anak-anak yang hidup di era globalisasi informasi seperti sekarang ini memang tidaklah mudah, yang penuh dengan kecanggihan teknologi. Tidak saja dibutuhkan keteguhan, kecakapan, kesabaran dan kearifan dalam bersikap tetapi juga dalam bertindak dalam penggunaan gadget secara tepat. Pada zaman sekarang dibutuhkan barang teknologi untuk melakukan kegiatan apapun. Hal ini menyebabkan peran orangtua penting terhadap perkembangan anak-anaknya yang semakin canggih dengan gadget yang mereka punya.

Gadget memang dibutuhkan untuk alat komunikasi, dan akses cepat dalam melihat berbagai informasi, sehingga pengawasan serta bimbingan orang tua terhadap anak harus selalu dilakukan. Karena jika orangtua terlena dengan anak yang bisa bermain gadget secara bebas lamakelamaan anak hanya bisa bermain gadget dan tidak bisa berkomunikasi dengan lingkungan sekitarnya. Sebaiknya orangtua mengenalkan gadget pada anak dan juga mengenalkan budaya atau tradisi dalam arti cara menghormati dan sopan santun dalam bermasyarakat, ehingga peran anak di masa yang akan datang menjadi lebih baik, dan penggunaan gadget dilakukan secara tepat guna.

\section{DAFTAR PUSTAKA}

Bayer, J. K. (2011). Risk Factors for Childhood Mental Health Symptoms: National Longitudinal Study of Australian Children. Pediatrics, 128(4), e1-e15. DOI: 10.1542/peds.2011-0491

Centers for Disease Control and Prevention. (2013). Children's Mental Health - New Report. Dalam CDC. Mental health surveillance among children - United States, 2005-2011. diakses tanggal 22 Juli 2018. dari situs http://www.cdc.gov/features/childrensmentalhealth 
Depkes RI \& IDAI. (2013). Stimulasi, Deteksi dan Intervensi Dini Tumbuh Kembang Balita Sosialisasi Buku Pedoman Pelaksanaan DDTK di tingkat Pelayanan Kesehatan Dasar. diakses dari http://www.scribd.com/doc/181177655/gds137slide-deteksi-dan-intervensi-dinitumbuh-kembang-balita-pdf

Erol, N., Simsek, Z., Oner, O., Munir, K. (2005). Behavioral and Emotional Problems among Turkish Children at Ages 2 to 3 Years. Journal of the American Academy of Child and Adolescent Psychiatry, 44(1), 80-7

Hastuti. (2012). Psikolog Perkembangan Anak. Yogyakarta: Tugu Publisher

Jonathan. (2015). Perancangan Board Game Mengenai Bahaya Radiasi Gadget terhadap Anak. Surabaya: Universitas Kristen Pertra Surabaya

Maulida, H. O. (2013). Menelisik Pengaruh Penggunaan Aplikasi Gadget terhadap Perkembangan Psikologis Anak Usia Dini. Jurnal Ilmiah Teknologi Pendidikan

Muhibbin, S. (2003). Psikologi Belajar. Jakarta: PT. Rajagrafindo Persada Hasil seminar pengaruh gadget terhadap perkembangan anak pada tanggal 25 september 2016

Ramadhan, A \& Agung, F. (2017). Hubungan tingkat kecanduan gedget dengan gangguan emosi dan perilaku remaja usia 11-12 tahun. Jurnal kedokteran diponogoro, 6(2). Online: http://ejournal-s1.undip.ac.id/index.php/medico ISSN Online : $2540-8844$

Suwarsi, J. (2015). Perancangan Board Game Mengenai Bahaya Radiasi Gadget terhadap Anak. Surabaya: Universitas Kristen Pertra Surabaya

Widyawati, I., Sugiman, H. E. (2014). Pengaruh Penggunaan Gadget terhadap Daya Kembang Anak. Seminar Nasional Multidisiplin Ilmu, 10, 6-12 